\title{
Late-medieval horse remains at Cēsis castle, Latvia, and the Teutonic Order's equestrian resources in Livonia
}

Article

Accepted Version

Pluskowski, A., Seetah, K., Maltby, M., Banerjea, R., Black, S. and Kalnins, G. (2018) Late-medieval horse remains at Cēsis castle, Latvia, and the Teutonic Order's equestrian resources in Livonia. Medieval Archaeology, 62 (2). pp. 351-379. ISSN 0076-6097 doi:

https://doi.org/10.1080/00766097.2018.1535385 Available at https://centaur.reading.ac.uk/82256/

It is advisable to refer to the publisher's version if you intend to cite from the work. See Guidance on citing.

To link to this article DOI: http://dx.doi.org/10.1080/00766097.2018.1535385

Publisher: Taylor \& Francis

All outputs in CentAUR are protected by Intellectual Property Rights law, including copyright law. Copyright and IPR is retained by the creators or other copyright holders. Terms and conditions for use of this material are defined in the End User Agreement. 


\section{CentAUR}

Central Archive at the University of Reading

Reading's research outputs online 
Late Medieval Horse Remains at Cēsis Castle, Latvia, and the Teutonic Order's Equestrian Resources in Livonia

By ALEKS PLUSKOWSKI, ${ }^{1}$ KRISH SEETAH, ${ }^{2}$ MARK MALTBY, ${ }^{3}$ ROWENA BANAJEA, ${ }^{4}$, STUART BLACK $^{5}$ and GUNDARS KALNINŠ 6

EXCAVATIONS AT the castle complex of Cèsis, Latvia, uncovered an unusual find of large quantities of horse bones, some of which were partially articulated, along with equestrian equipment. These were associated with a destroyed building at the edge of the southern outer bailey. The horses included large males, most probably stallions, and pathology on several of the recovered vertebrae suggest these individuals had been used for riding. The size of the horses was within the range for medieval war horses, and the associated tack also pointed to prestigious riding animals. Radiocarbon dating of the bones placed them firmly within the Teutonic Order's period of rule. We conclude here that these horses fulfilled a military role in final decades of the Teutonic Order's rule in Livonia in the late15th/early 16th century, and that the better-known equestrian culture of late-medieval Prussia was comparable in character, if not in scale, to that in Livonia.

Over the course of the 13th century, the tribal territories of the eastern Baltic were conquered by crusading armies and re-organised as the Christian polities of Livonia and Prussia. With the exception of the Danish Duchy of Estonia these were governed by militarised theocracies - the Teutonic Order, bishops and their cathedral chapters. In the case of Livonia, power was split between four episcopates, cities - particularly Riga (now in Latvia) - and the Teutonic Order, which in AD 1237 had absorbed the remnants of the locally established military order, the Sword Brothers, who had been vassals of the archbishops of Riga. The Teutonic Order's Livonian estates were overseen by a provincial master, with individual territories governed by commanders (German Komtur) and advocates (Vogt). These officials were based in castles, the largest of which were effectively fortified convents, and their principal roles concerned the maintenance of order, the management of resources and the provision of security. The Teutonic Order promoted itself as the defender of Latin Christendom in north-eastern Europe against pagan Lithuania and Eastern Orthodox Russian principalities, particularly Novgorod. ${ }^{7}$ Compared to Prussia, the surviving written sources for Livonia are extremely limited and fragmentary, ${ }^{8}$ but they indicate that by the 15th century, and almost certainly earlier, the Teutonic Order had mobilised substantial military resources at its castles. ${ }^{9}$

One of the most important elements of these was horses. The war horse, along with the crossbow, has been considered pivotal to the military successes of crusading armies in the eastern Baltic, ${ }^{10}$ and came to define the power of the new regime. Horses consistently feature in the visitation records of the Teutonic Order's castles in both Prussia (where they are far better documented) and Livonia. Each castle had ownership of its own equine stock, but could also procure cavalry or pack horses from its vassals through corvée - the tenurial obligations imposed on both the conquered population and incoming colonists following the Crusades. Our knowledge of the Order's equine resources is largely based on Prussian sources, and until recently there has been little comparative data from Livonia. However, a zooarchaeological survey of horses across the eastern Baltic before and after the Crusades has provided a baseline for assessing finds of equine remains from Livonian sites. ${ }^{11}$ Horse remains are typically found at the Teutonic Order's castles during excavations, but they are usually disarticulated and highly fragmented. Excavations at the castle complex at Cēsis in 
Vidzeme, central Latvia (German Wenden) uncovered a rare find. The remains of both articulated and disarticulated horses were exposed, along with equestrian equipment, in stratigraphic horizons associated with a destroyed building at the edge of the southern outer bailey. This provided a new opportunity to contextualise the equestrian resources utilised by the Livonian branch of the Teutonic Order within the broader context of the eastern Baltic.

\section{EXCAVATIONS AT CËSIS CASTLE}

The castle complex had been the focus of over three decades of excavations (19742008), directed by Zigrīda Apala. ${ }^{12}$ Much of the area within the castle was excavated during this time, including the remains of the western range which was detonated by the castle inhabitants on 6 September 1577 during the Russian siege. In 2010, surveys of the southern outer bailey and moat were conducted with a gradiometer and ground penetrating radar, within the context of 'The Ecology of Crusading' project. ${ }^{13}$ The aim was to identify areas with undisturbed cultural deposits and to recover a range of environmental data. This was followed by targeted excavations in 2011 and 2012, consisting of a $2 \mathrm{~m} \times 5 \mathrm{~m}$ trench $(\mathrm{N})$ in the moat; a $2 \mathrm{~m} \times 10 \mathrm{~m}$ trench (M) in the southern outer bailey; and three small trenches within the western part of the castle targeting discrete sedimentary deposits. A diverse range of ecofacts and artefacts were recovered during these excavations. The earliest phases could be dated by the dendrochronology of associated timber structures and linked to the expansion of the castle in the later 14th century. These were small-scale excavations largely aimed at recovering a suite of environmental data. The horse bones were found in trench $\mathrm{M}$.

Trench $\mathrm{M}$, opened in the south-western corner of the southern outer bailey (Fig 1 ), was excavated over the course of two seasons. Initially a $2 \mathrm{~m} \times 8 \mathrm{~m}$ trench was opened in 2011 , and this was extended to the east by two metres in 2012 to determine whether an uncovered wall was internal or external. The excavation area was opened along a raised platform of soil, the edge of which corresponded to the outer wall of a range represented on later maps of the castle. ${ }^{14}$ Traces of several phases of construction, destruction and rebuilding were uncovered. The soil was waterlogged at a depth of c $2.8 \mathrm{~m}$ (Fig 2), where a substantial timber, probably a sill plate, lay directly on top of the natural geology (Fig 3). This was dated by dendrochronology to C AD 1374/5 and its use may have been secondary, or it may have derived from a timber-framed building constructed in situ. The chronology of the main destruction layer is discussed in further detail below, but the sequence of activities in this part of the castle's precinct appears to begin no earlier than the mid-14th century. The structure appears to have been subsequently rebuilt (as represented by a horizon of brick rubble) and then used until the end of the 15th/start of the 16th century (see section on dating below), at which point it was destroyed by fire. This destruction horizon consisted of a dark soil layer (044 / 063) with unevenly distributed charcoal and ash, c 1.75-1.85 m deep and with an average thickness of $10 \mathrm{~cm}$ across the profile. ${ }^{15}$ Embedded within this were a series of charred timbers most of which lay on a S/N axis (see Fig 4), as well as a small lens of mortar. The horse remains, which were recovered above and between these timbers, were situated within a layer (033) covering the charred timbers, with an average thickness of $50 \mathrm{~cm}$. The structure was then rebuilt with the addition of a stove and the roof was retiled; remnants of stove and roof tiles were found throughout the upper horizons. This structure was subsequently demolished and rubbish pits were dug into the ground, truncating the occupation deposits in the western area of the trench. Geochemical and 
macrobotanical analyses indicated the area contained middens in both its earlier and later phases. ${ }^{16}$ Fragments of bone from cattle (Bos taurus), sheep/goat (Ovis aries / Capra hircus), pig (Sus scrofa), dog (Canis I familiaris), chicken (Gallus gallus domesticus) and hare (Lepus sp.) were also found throughout the section.

THE HORSE REMAINS FROM THE OUTER BAILEY

A total of 1719 fragments of animal bone were recovered from trench $M$, of which 843 (49\%) were identifiable at species level. Of these identifiable fragments, 369 were associated with contexts dating to the period of the Teutonic Order's rule. The majority of these, 251 fragments, were identified as belonging to a minimum number (MNI) of four horses (Equus caballus), calculated using the most frequently occurring zone of the tibia (Tab 1). ${ }^{17}$ The horse bones were all recovered from the phase of destruction c 1.75-1.85 m below the surface. One hundred and thirty four fragments were defined as an 'Associated Bone Group' (ABG1) in situ, representing $65 \%$ of an entire individual (a horse typically has 205 bones). The horse lay curled on its left side on top of the destruction layer with the head facing towards the south-east, and its bones showed no signs of burning. The skull and atlas (first cervical vertebra) were heavily fragmented when the stove was subsequently constructed on the levelled surface (Fig 5). Some of the ribs had also been pushed to the west. One side of the mandible was complete, with intact cheek teeth (P2, P3, P4, M1, M2, M3) all showing signs of wear. Measurements of the crown heights of the third premolar indicated the articulated individual was aged $17-18$ years. ${ }^{18}$ Visible portions of a femur and tibia, alongside the fragmented pelvis, were embedded within the S-facing profile, but the latter was successfully recovered (Fig 6). The other three individuals were represented by an associated set of 18 thoracic vertebrae (ABG2), a set of three associated phalanges (ABG3) and a range of incomplete and disarticulated elements (see Tab 1), although all were recovered close to each other within the area defined by the charred timbers. At least two bones, including an identifiable horse humerus, remained embedded in the S-facing profile. Of these remains, only eight fragments, all from lower limb elements, displayed signs of charring, but no element was completely burnt (Fig 7, Tab 2). All the bones were fully fused, indicating the animals were adults, whilst three individuals - represented by separate groups of fused vertebrae (ABG1, ABG2 and additional thoracic elements) - were aged to at least five years. ${ }^{19}$ Measurements of the crown heights of the third premolar from two individuals within the destruction layer indicated one was aged 17-18 years and the other 10-12 years. The skull of the articulated horse was identified as male due to the presence of canine teeth. Four loose canines were also found amongst the disarticulated remains.

The greatest lengths of six of the limb bones were used to estimate withers height based on Vitt (for the list of measurements see Tab 3). ${ }^{20}$ These estimates ranged from between 135 to $147 \mathrm{~cm}$, averaging $141 \mathrm{~cm}$. These horses are larger than the majority recorded from late-medieval Prussia, ${ }^{21}$ and the prehistoric ranges for Latvia and Estonia. ${ }^{22}$ The metrical data confirm the documented presence of both small and large horses in Livonia, comparable to that in Prussia. In the latter region, the war horses bred on the Order's estates reached estimated heights of up to $150 \mathrm{~cm}$, whilst indigenous horses could be as small as $101 \mathrm{~cm} \cdot{ }^{23}$ In Livonia, the smallest horses stood at an estimated $112 \mathrm{~cm} \cdot{ }^{24} \mathrm{In}$ neighbouring Novgorod, where substantial numbers of horse remains have been found, withers heights from 93 complete limb bones from the Troitsky sites averaged around 1.33 $\mathrm{m}$ with a range of $1.17-1.53 \mathrm{~m}$; from Gorodishche the average height was $144 \mathrm{~cm} .{ }^{25}$ The most complete $A B G$ from trench $M$ at Cēsis had pathology on ten of the 18 thoracic 
vertebrae (T8-T18), consisting of overriding dorsal spinous processes, as well as spondylotic spurs of newly formed bone on the ventral and lateral surfaces of the lower vertebral bodies (Fig 8). The same pathology was also visible on the same ten thoracic vertebrae from AGB2, deriving from another individual. Other pathologies from ABG1 included extensive chronic deformation of a single tarsal resembling spavin, and on the medial surface of a right metacarpal, which may have reflected the start of the ossification of the interosseous ligament. ${ }^{26} \mathrm{~A}$ small amount of pathological bone growth on a separate rib fragment was also observed.

These are relatively minor pathologies compared to other finds of pathological horse spines from medieval contexts in the eastern Baltic Sea region, where adjacent sets of thoracic and lumbar vertebral bodies and their processes were fully fused. ${ }^{27}$ In Livonian sites, examples of similar pathologies on horse thoracic vertebrae have been found in suburban contexts in Viljandi (German Fellin). ${ }^{28}$ It is noteworthy that such examples have also been found at other castles associated with the Teutonic Order. ${ }^{29}$ The causes can reflect a variety of factors, including stresses related to traction, such as pulling carts or ploughs, and as such can manifest in older animals. Indeed, of the three individuals which could be aged by crown height measurements, two were very old. However, given the large size of the horses and their association with luxury riding tack (see below), these pathologies may have developed because of the stresses of being ridden by heavily armoured knights. Barding (armour for horses) became popular for war horses in the 14th and 15th centuries, and by the mid-15th century was defined by a combination of metal plates and leather. However, this type of armour was relatively light; for example, a crinet, protecting the neck of a horse, only weighed around $4-5 \mathrm{~kg}$. On the other hand, the average weight of steel armour was $20-25 \mathrm{~kg}$, and when combined with the weight of a knight this would have added a load of 70-90 kg. ${ }^{30}$ Such a weight would result in excessive dorsiflexion, causing the vertebrae to rub against each other. In modern horses, which carry lighter loads, such lesions are typically detected in the saddle-bearing part of the back, between vertebrae T12 and T18, and are commonly referred to as 'kissing spines'. ${ }^{31}$

Previous seasons of excavations at Cēsis Castle have also uncovered partially articulated horse skeletons. In 1927 the skeleton of a horse was found on the stairs leading down to the basement of the western range of the castle. ${ }^{32}$ During excavations of the western range in 2005, two partial skeletons were found: one at the north-eastern corner (with a skull but lacking the lower jaw) and the other at the north-western corner (without a skull) of basement room 3. Little information is available on the condition of these remains and they were not subsequently available for further analysis. However, it can be tentatively assumed in these cases that the horses were killed by the detonation of the Western Range in 1577.

\section{ISOTOPIC ANALYSIS}

Stable isotope analysis was conducted (oxygen, ' $\mathrm{O}$ ' and hydrogen, ' $\mathrm{H}$ ') on bone collagen, and trace element analysis (barium, 'Ba' and magnesium, ' $\mathrm{Mg}$ ') of bone phosphate applied to the excavated Cēsis horse remains. $\mathrm{O}-\mathrm{H}$ isotopes have been analysed previously on bone collagen for both humans and animals, ${ }^{33}$ and the influence of water uptake on the oxygen and hydrogen isotope composition of human and animal tissues has been well established for decades. ${ }^{35}$ The isotopic analyses were carried out at the Department of Archaeology at the University of Reading (United Kingdom) using the Chemical Analytical Facility (CAF). Bone collagen was extracted following the method described by Britton, 
Müldner and Bell. ${ }^{36}$ Oxygen and hydrogen stable isotope ratios were measured in triplicate on a Thermo-Fisher DeltaV Advantage Isotope Ratio Mass Spectrometer coupled to a Smart TC/Elemental Analyzer. Sample data was taken as averages of triplicate analyses with 2 SD (standard deviation) variations expressed as uncertainty bars. Analytical error was calculated by repeated analyses of internal and international standards and was less $<0.1 \%$ for oxygen and $<2.3 \%$ for hydrogen ( $2 \mathrm{SD}$ ).

Linda Reynard and Robert Hedges (2008) established the basis of working with O-H data from collagen following previous work. ${ }^{37}$ They established the need to calculate the exchangeable hydrogen content of collagen as hydrogen is absorbed from the atmosphere and water being used in the analytical process. In order to correct the data for the effects of hydrogen absorption, a fractionation experiment was conducted whereby six different collagen samples, in triplicate, were exposed to water of different isotopic compositions. Linear correlations were established for each sample plotting water isotope $(\mathrm{O}$ and $\mathrm{H}$ ) against measured $\mathrm{O}$ and $\mathrm{H}$ isotope ratios in exposed collagen. These data showed a consistent offset between water isotope $(\mathrm{O}$ and $\mathrm{H})$ and measured values of between ten and $19 \%$. The mean of these $(11+/-3 \%)$ was used to correct the measured collagen data for any absorption effects during analysis.

Samples of metapodial, rib, ulnar carpal, ulna and occipital skull bone sections from recovered horse skeletons were analysed for trace elements. The samples were physically cleaned of any altered outer margins using a Dremel drill prior to sub-sampling. The drill head was a burr and sand paper set to remove the surface. Cleaned samples were then washed in UHQ water in an ultrasonic bath to remove any residual soil particles, before being soaked in a $0.1 \mathrm{M} \mathrm{HCl}$ solution to remove any deposited carbonates and other soluble materials. ${ }^{38}$ Once air dried, the samples were drilled from cross sections of bones to ensure no altered material was selected. Dried bone powder was then dissolved in concentrated HNO3 until complete digestion was obtained. The dissolved samples were then diluted and a series of internal standards ( $\mathrm{Rh}, \mathrm{In}$ and $\mathrm{Re}$ ) added to the solutions prior to analysis on a Thermo Fisher iCAPQ ICP-MS which was calibrated with a series of multi-element standards. The instrument was run in KED mode (with the collision/reaction cell on) to prevent polyatomic interferences and to increase sensitivity. Blank deductions were made following procedural blanks and several international standards run alongside the samples.

Trace element concentrations in archaeological bone have been discussed in detail in the literature, ${ }^{39}$ with studies suggesting that analyses were complicated and dogged by issues of post-burial alteration. ${ }^{40}$ However, more recent work on trace element uptake to bone suggests that these data can be useful, and inert elements such as barium and magnesium can be used to interpret in vivo concentrations. ${ }^{41}$ Whilst post-mortem burial environments can affect trace element content of bone, ${ }^{42}$ Barium and magnesium are relatively immobile in hydrological environments and so we are confident the Cēsis horse trace element data represents in vivo values. Barium concentrations in diets of animals can be associated with cereals and other alkaline earth concentrated foodstuffs (e.g. nuts, cereals, carrots, beans, onions).$^{43}$ In addition, magnesium also shows similar traits although is noted as being more mobile within the burial environment. ${ }^{44}$ However, thorough cleaning of bone samples as undertaken in this study and comparison of trace element ratios and immobile elements suggests that the concentrations measured here are close to that in vivo. In order to confirm this, trace element ratios were checked to ensure they were in previously reported ranges. ${ }^{45}$ Magnesium, barium, phosphorus, ' $\mathrm{P}$ ', uranium, ' $\mathrm{U}$ ' and vanadium, ' $V$ ' were monitored in all bone samples in order to assess the level of post-burial 
alteration. From the U-Series (Uranium Series) dating of the bone samples (see below), it is clear that elements such as uranium are taken up post burial. However, quantifying the proportion of uptake is possible by comparing elements such as uranium and vanadium that are not readily bioprecipitated into hydroxyapatite bone matrix to bone samples that have not been interred. These elements can be used as useful markers for alteration of bone samples and give a broad indication of the level of post-burial diagenesis.

In the case of vanadium animal tooth enamel, dentine and bone have been shown to have concentrations of $0.1-0.6 \mathrm{mg} / \mathrm{kg},{ }^{46}<1.5 \mathrm{mg} / \mathrm{kg},{ }^{47}$ and $<0.08 \mathrm{mg} / \mathrm{kg},{ }^{48}$ respectively. Similarly, uranium substitution into bone is a good indicator that other elements such as $\mathrm{Sr}$, (strontium), Ba and Mg would have been similarly affected. Concentrations of vanadium in the bone samples from this study are all low $<0.5 \mathrm{mg} / \mathrm{kg}$, and most $<0.1 \mathrm{mg} / \mathrm{kg}$. Similarly, uranium concentrations are also low $(<0.3 \mathrm{mg} / \mathrm{kg})$ indicating that post-burial, diagenetic alteration of bone samples is minimal including elements likely to substitute or ionically exchange into the bone samples post burial. In addition, elements that are also typically low in bone concentrations in vivo (such as REE, some trace metals) are also either below detection limit on similarly low concentrations (see Supplementary Material 1). ${ }^{49}$ In summary, the stable isotope data (Fig 9) show that the Cēsis horses consumed local water and these data are consistent with previously published data. ${ }^{50}$ The trace element data (Fig 10) show that the Cèsis horses consumed high Mg and Ba foods, possibly grain, and compared to other horses analysed within the framework of the 'Ecology of Crusading' project they were being fed differently which supports the zooarchaeological interpretation of these individuals as war horses. ${ }^{51}$

HORSE EQUIPMENT FROM THE OUTER BAILEY

Horse equipment excavated in association with the horse bones was found immediately below the burnt layer with charred timbers. This consisted of elements from a stirrup, three unidentifiable linear objects and a large lump of unidentifiable iron, four copper-alloy bridle bosses with associated textile/leather fragments, in one case connected to a fragment of curb chain, an iron saddle frame, five (possibly six) additional stirrups and a fragmented iron horseshoe (Figs 11-13). Two of the stirrups recovered on top of each other $<002>$ were different in design, suggesting they did not form a pair, whilst two lying in close association were identical $<004>$. A third phalanx from a horse (part of ABG3) uncovered in the south-facing section in 2012 was also directly associated with an iron horseshoe and nails. The artefacts were X-rayed at the Pranas Gudynas Restoration Centre (Vilnius, Lithuania) and at the hospital in Cēsis, revealing details of the bridle attachments (Fig 14). A comprehensive description of the assemblage will be published after the completion of its ongoing conservation.

At present, the decorated circular bosses provide the most reliable means of dating the set of equipment - two depict a raised leonine head, one is a studded disc with a dome, and the last has two concentric ridges and is also domed (Figs 15-17). Similar tack is clearly depicted on Pisanello's 'Vision of St Eustace' (C AD 1438-42) and on 'The Triumphal Procession of Emperor Maximilian I' by Albrecht Altdorfer and his workshop (c AD 1512-15) (Fig 18). In addition to the identifiable tack, a series of associated, unidentified iron objects resembling small plates were uncovered within the south-facing section in 2012; the overall dimensions of this exposed mass were $210 \mathrm{~mm} \times 90 \mathrm{~mm}<061>$. Given their fragile state, it was decided to leave them in situ, covered by a protective sheet. They may be the remnants of brigandines - small plates sewn into fabric and used as part of horse barding in the 15th 
century. The closest artistic representation of this type of barding can be found on Pisanello's tournament fresco in the Palazzo Ducale in Mantua, dating to C AD 1439-42 (Fig 19). The Cēsis horse tack clearly belongs to the European cultural sphere in contrast to neighbouring Russia, where the tack was relatively simple until the early 17 th century when both 'horse cultures' began to converge. ${ }^{52}$

In summary, the horse equipment associated with the destruction layer and fragmented horse bones can be broadly dated to the late 15th-/early 16th-century. Although a small element may represent a type of ornamental barding, it largely consists of a form of decorative tack that was popular amongst the aristocracy in other parts of Europe, including the Holy Roman Empire - the principal source of recruits for the Teutonic Order. Although no plate barding was uncovered in trench $M$, several pieces of shaffron (horse head armour) have been found during previous excavations at the castle (Fig 20). ${ }^{53}$

\section{DATING THE HORSE REMAINS}

During the excavation of trench $\mathrm{M}$, the discovery of the horse remains led to the assumption that traces of the Russian siege of the castle in AD 1577 had been uncovered. The associated material culture, mostly consisting of smashed roof tiles with additional debris from subsequent demolition layers, including large quantities of largely fragmented stove tiles, was difficult to date precisely - the relative chronological ranges were too broad. Fragments of horse bone were therefore sent for Accelerated Mass Spectrometry (AMS) dating and U-Series dating. The resulting AMS date (SUERC-47219) shows the highest probability range (71.4\%) from C AD 1429-1524, whilst the U-Series date was AD 1503 +/-35 years ( 2 sigma), giving a median range of both dates to be C AD AD 1480-1503 for the most likely range of the horse remains (Fig 21)..$^{54}$ Both dates indicate the horses most likely expired many decades before the siege of AD 1577 (Fig 21). Moreover, the construction of residential quarters on top of the remains and burnt timbers corresponds to the presence of mercenaries at the castle from the mid-16th century. The overall conclusion is that the horses are more likely associated with the later phase of the Teutonic Order's rule in Livonia, spanning a period defined by the reigns of six provincial masters.

HORSES AT WENDEN IN THE FINAL PHASE OF THE TEUTONIC ORDER'S RULE

The establishment of the Teutonic Order's theocratic regime in the eastern Baltic is associated with the professionalisation of cavalry. In Livonia, where the written record for the Order's holdings is relatively limited and fragmentary, this is evident from references to horse management in castles and towns, obligations of military service which included the provision of horses - specifically war horses - and castle inventories. ${ }^{55}$ Horse remains found in the castles of the Order and episcopates in Livonia indicate that horses were kept and disposed of within their precincts. As in the case of the Teutonic Order's other large fortified convents, horses were probably distributed across several areas of Wenden Castle, rather than being solely stabled in one building. ${ }^{56}$ There is some tentative evidence that the equine resources of Wenden's commandery improved by the 16th century. In 1451, only 17 horses are listed at the castle, ${ }^{57}$ whilst by 1551 the commandery could field 300 horses $^{58}$ This may have been the result of the policies of the most famous Livonian master, Wolter von Plettenberg (C AD 1494-1535), who is known to have employed heavy cavalry in his wars against the Russian principalities, as at the Battle of Siritsa River in $1501 .{ }^{59} \mathrm{~A}$ document issued by Plettenberg in AD 1526 also referred to the town of Wenden's horse pasture, which was situated in Duppen parish. ${ }^{60}$ By the time of the Livonian War, there were still a 
large number of horses in Wenden. In February 1578, a famine resulted in 124 horses being killed and eaten, with their entrails given to the poor. ${ }^{61}$ The fragmentary written sources indicate that the Order's wealthier vassals were obligated to provide horses, but animals could also be sourced from further afield; procured during raids on Lithuanian territories, captured in battle or transported across the Order's Baltic estates; the Livonian land marshal sent horses to the grand master in $1463 .{ }^{62}$

Medieval war horses were typically $142-152 \mathrm{~cm}$ tall at the shoulder, ${ }^{63}$ and whilst the Cēsis horses average at c $141 \mathrm{~cm}$, the upper estimate (of the overall range of c 135-147 cm) is well within the war horse size category. A slight increase in the size of horses can be observed after the Crusades in both Livonia and Prussia based on the zooarchaeological data analysed to date. ${ }^{64}$ This almost certainly reflects the breeding of larger horses for heavy cavalry which are noted in written sources as a distinguishing feature of the Order's military assets, whilst at the same time maintaining and breeding indigenous stock as pack animals and for traction. ${ }^{65}$ Transformations in warfare over the course of the 16th century resulting from the proliferating use of firearms saw the gradual abandonment of fully armoured mounted knights in favour of lighter, more agile cavalry. The Russians had long-used lightly armoured cavalry but shortly before the Livonian War (1558-1583) the military reforms of Tsar Ivan IV Vasilyevich ('the Terrible') included making infantry units with firearms a permanent feature of Muscovite armies. Whilst Polish-Lithuanian cavalry was dominated by heavier armoured hussars who relied on shock charges during this time, infantry came to play an increasingly dominant role. ${ }^{66}$ In this respect, the Teutonic Order's period of rule in Livonia bookends two formative periods in eastern Baltic horse culture - the introduction of heavy European cavalry with the Crusades and its transformation in response to changing battlefield technology and the experiences of the Livonian War, during which the Order's Livonian branch was secularised.

\section{CONCLUSION}

Articulated and partial horse skeletons are not infrequently found in medieval archaeological contexts. They represent solutions to the disposal of large carcasses in a regulated environment, ${ }^{67}$ perhaps the end stage of knackering, ${ }^{68}$ or animals killed during a siege (eg Jacob's Ford in 1179, Kingdom of Jerusalem, today Israel) ${ }^{69}$ or in battle (eg Grunwald in 1410, Prussia, today Poland)..$^{70}$ In the pre-Christian eastern Baltic, horses were also deposited in cemeteries, a practice that seems to have ended following the Teutonic Order's conquest. ${ }^{71}$ In the Order's Baltic castles, horse remains are regularly found but they are typically disarticulated and reflect carcass disposal. ${ }^{72}$ The horses uncovered in the outer bailey of Cēsis Castle are unusual insofar as they were associated with prestigious equestrian equipment. In the late-15th or early 16th century, the building in the outer bailey of the castle, tentatively interpreted as a stable, was destroyed by fire. The debris included equestrian equipment, which appears to have been stored in the building rather than worn by any horses at the time, although at least one of the animals was shod. The artefacts were found partially resting on some stone slabs, which may have been part of a floor as 11 stones were uncovered in this area.

The area was briefly used for waste disposal as suggested by the macrobotanical and additional fragmented faunal remains. Therefore the deposit is generally characterised as the abandonment phase of the structure in the outer bailey, where the destroyed building was reused as a dumping area. ${ }^{73}$ The geochemistry from the mixed rubble layer (33) does not have the same levels of enrichment as in earlier layers, whilst the raised level of calcium 
could even represent decayed mortar. It is difficult to determine whether the horses were killed by the collapse or whether their carcasses were deposited amongst the debris. The lack of charring on the majority of the bones may suggest that the horses were suffocated, or killed by falling timbers, roof tiles and other debris. The fact that horseshoes were still attached to the distal phalanges of at least one animal suggests that their recovery at the time was difficult or, given the nature of the disaster, undesirable. The articulated individual (ABG1) was not associated with any artefacts.

These horses included large male individuals, most probably stallions. The pathology on several of the recovered vertebrae may be connected with the fact that at least two horses present were much older animals, although combined with the size and sex of the individuals, this paper has argued for riding animals as a plausible explanation. The size of the horses is above the average for horse height in medieval Prussia, Livonia and western Russia. The tack found with the horses also points to prestigious riding animals, and whilst no plated barding was uncovered in the outer bailey, it is likely that such animals would have fulfilled a military rather than an agrarian role. It is therefore entirely plausible that the horse remains in the outer bailey derived from war horses, although the associated tack was largely ceremonial. The destruction of the 'stable' must have been so severe that, instead of searching through the debris and recovering what remained of the tack, a decision was made to cover the remnants, level the rubble and rebuild the structure. The insertion of a stove indicates the new building was intended to have a residential role. A more extensive excavation of this part of the outer bailey would conceivably result in the recovery of more horses and associated material culture, clarifying the scale of the destruction and the number of animals killed. It would be possible to determine whether all the animals were deposited here after the initial destruction of the building. As an archaeological assemblage, they contribute a striking - and otherwise unknown - episode in the story of the final decades of the Teutonic Order's rule in Livonia. They also indicate that the better-known equestrian culture of late medieval Prussia was comparable in character, if not in scale, in Livonia.

\section{ACKNOWLEDGEMENTS}

The authors are grateful to Dr Zigrīda Apala who led the two seasons of excavations of the 'stable' at Cēsis Castle, and to the students who participated. We would also like to thank the National History Museum of Latvia, the Institute of Latvian History and Prof Arnis Mugurēvičs. The conservation of the horse equipment was carried out by Alaina Schmisseur (University of York), in association with the conservation department of Cēsis Castle Museum and the Lithuanian Art Museum. The AMS dating was carried out by SUERC (Glasgow) and U-series dating by Dr Stuart Black (Reading). Dendrochronological dating was carried out by Dr Māris Zunde (Dendrochronological laboratory, Institute of Latvian History). We would also like to thank Dr Gundula Müldner (University of Reading) for additional comments. The research leading to these results has received funding from the European Union's Seventh Framework Programme (FP7/2007-2013) under grant agreement no 263735.

Apala, Z 2007, 'Cesu pils arheoloǵiskās izpētes (1974-2006) rezultāti', in Rozentāle et al, 4576. 
Apala, Z 2010a, 'Jaunākie arheoloǵiskie pētījumi Cēsu Riekstu kalnā', Arheologu Pētījumi Latvijā 2008/2009, 35-40.

Apala, Z 2010b, 'Pabeigta Cēsu viduslaiku pils pagalma arheoloǵiskā izpēte', Arheologu Pètījumi Latvijā 2008/2009, 65-8.

Apala Z 2010c, 'Arheoloǵiskie pētījumi Cēsu Rožu laukumā', Arheologu Pētījumi Latvijā $\mathbf{2 0 0 8 / 2 0 0 9 , 6 8 - 7 2 . ~ N o t ~ i n ~ f n ~}$

Baker, J and Brothwell, D 1980, Animal Diseases in Archaeology, London: Academic Press.

Banerjea, R and Badura, M forthcoming 2018, 'Settlement life in Livonia and the impact on hinterlands: The geoarchaeological and archaeobotanical evidence', in Pluskowski (ed).

Bennett, M 1995, 'The medieval warhorse reconsidered' in S Church and R Harvey (eds) Medieval Knighthood V, Woodbridge: Boydell, 19-40.

Benninghoven, F 1963, 'Probleme der Zahl und Standortverteilung der livländischen Streitkräfte im ausgehenden Mittelalter', Zeitschrift für Ostforschung 12, 601-22.

Black, S forthcoming 2018, 'Appendix 2: Uranium series dating', in Pluskowski (ed).

Bliujienè, A (ed) 2009, The Horse and Man in European Antiquity (Worldview, Burial Rites and Military and Everyday Life), Archaeologia Baltic 11 (special issue), Klaipèda: Klaipèda University Press.

Bourdillon, J 1993, 'Animal bone', in J Hawkes and M Heaton, Jennings Yard, Windsor, A Closed-Shaft Garderobe and Associated Medieval, Wessex Archaeology Report 3, Salisbury: Trust for Wessex Archaeology, 67-79.

Breiding, D H 2005, 'Horse armour in medieval and Renaissance Europe: An overview', in S W Pyhrr, D J LaRocca and D H Breiding (eds), The Armored Horse in Europe: 14801620, New Haven, Conneticutt and London: Yale University Press, 8-18.

Britton, K, Müldner, G and Bell, M 2008, 'Stable isotope evidence for salt-marsh grazing in the Bronze Age Severn Estuary, UK: Implications for palaeodietary analysis at coastal sites', J Archaeol Sci 35, 2111-18.

von Bruiningk, H 1908, Livländische Güterurkunden (aus den Jahren 1207 bis 1545), vol 1, Riga: Komissionsverlag von Janck und Poliewsky.

von Bunge, F G et al (ed) 1853-1857, Liv-, Est- und Kurländisches Urkundenbuch nebst regesten, [Book of Certificates and Register for Livonia, Estonia and Courland], 3 vols, republished 1967-81, Aalen: Scientia Verlag.

Burton, J and Price, T 1990 'The ratio of Barium to Strontium as a paleodietary indicator of consumption of marine resources', J Archaeol Sci 17, 547-57.

Caune, A 2007, 'Cesis 14.-18. Gadsimtā: plānojums, apbūve un iedzīvotāji', in Rozentāle et al, 155-66.

Cowie, R, Pipe, A and Clark, J et al 1998, 'A late medieval and Tudor horse burial ground: excavations at Elverton Street, Westminster', Archaeol J 155:1, 226-51.

Daugnora, L and Thomas, R 2005, 'Horse burials from Middle Lithuania: a palaeopathological investigation', in J Davies, M Fabiš and I Mainland et al (eds), Diet and Health in Past Animal Populations: Current Research and Future Directions, Oxford: Oxbow, 67-74.

Dunsdorfs, E and Spekke, A 1964, Latvijas vēsture. 1500-1600, Stockholm: Daugava.

Ekdahl, S 1991, 'Das Pferd und seine Rolle im Kriegswesen des deutschen ordens', in Z H Nowak (ed), Das Kriegswesen der Ritterorden im Mittelalter, Toruń: Uniwersytet Mikołaja Kopernika, 25-47. 
Ekdahl, S 1998, 'Horses and crossbows: Two important warfare advantages of the Teutonic Order in Prussia', in H Nicholson (ed), The Military Orders 2: Welfare and Warfare, Aldershot: Ashgate, 119-51.

González-Weller, D, Rubio, C and Gutiérrez, A J et al 2013, 'Dietary intake of barium, bismuth, chromium, lithium, and strontium in a Spanish population (Canary Islands, Spain)', Food Chemical Toxicol 62, 856-68.

Hambleton, E 1999, Animal Husbandry Regimes in Iron Age Britain. British Archaeological Reports Series 282, Oxford: Archaeopress.

Hartmann, S 2008, Herzog Albrecht von Preussen und Livland (1560-1564), Köln: Böhlau.

Hinz, E A and Kohn, M J 2010, 'The effect of tissue structure and soil chemistry on trace element uptake in fossils', Geochimica et Cosmochimica Acta 74, 3213-3231.

Hobson, K A, Atwell, L and Wassenaar, L I 1999, 'Influence of drinking water and diet on the stable-hydrogen isotope ratios of animal tissues', Proc Nation Acad Sci 96:14, 80036. <https://doi.org/10.1073/pnas.96.14.8003>. [Accessed 1 October 2018].

Janeczek, M, Chrószcz, A and Onar, V et al 2014, 'Anatomical and biomechanical aspects of the horse spine: The interpretation of vertebral fusion in a medieval horse from Wrocław (Poland)', Internat J Osteoarchaeol 24, 623-33.

Jóźwiak, S and Trupinda, J 2012, Krzyżackie zamki komturskie w Prusach, Toruń: Wydawnictwo Naukowe Uniwersytetu Mikołaja Kopernika.

Kirsanow, K, Makarewicz, C and Tuross, N 2008, 'Stable oxygen $\left(\delta^{18} \mathrm{O}\right)$ and hydrogen ( $\left.D D\right)$ isotopes in ovicaprid dentinal collagen record seasonal variation', J Archaeol Sci 35, 3159-3167.

Kleimola, A M 2005, 'Cultural convergence: The equine connection between Muscovy and Europe', in K Raber and T J Tucker (eds), The Culture of the Horse: Status, Discipline, and Identity in the Early Modern World, Basingstoke: Palgrave Macmillan, 45-62.

Kohn, M, Morris, J and Olin, P 2013, 'Trace element concentrations in teeth - a modern Idaho baseline with implications for archaeometry, forensics and palaeontology', J Archaeol Sci 40, 1689-99.

Koon, $\mathrm{H}$ and Tuross, N 2013, 'The Dutch whalers: a test of a human migration in the oxygen, carbon and nitrogen isotopes of cortical bone collagen', World Archaeol 45:3, 36072.

Kreem, J 2002, The Town and its Lord: Reval and the Teutonic Order (in the Fifteenth Century), Tallinn: Tallinna Linnaarhiiv.

Kupisz, K 2012, 'The Polish-Lithuanian army in the reign of King Stefan Bathory (1576-1586)', in B J Davies (ed), Warfare in Eastern Europe 1500-1800, Leiden: Brill, 63-92.

LaMotta, V M and Schiffer, M B 1999, 'Formation processes of house floor assemblages', in P M Allison (ed), The Archaeology of Household Activities, New York: Routledge, 1929.

Levine, M A 1982, 'The use of crown height measurements and eruption-wear sequences to age horse teeth', in B Wilson, C Grison and S Payne (eds), Ageing and Sexing Animal Bones from Archaeological Sites, Brit Archaeol Rep 109, Oxford: Archeopress, 22350.

Levine, M A, Whitwell, K E and Jeffcott, L B 2005, 'Abnormal thoracic vertebrae and the evolution of horse husbandry', Archaeofauna 14, 93-109.

Leyden, J L, Wassenaar, L I and Hobson, K A et al 2006, 'Stable hydrogen isotopes of bison bone collagen as a proxy for Holocene climate on the Northern Great Plains', Palaeogeogr, Palaeoclimatol, Palaeoecol 239, 87-99. 
Losee, F L, Curzon, M E J and Little, M F 1974, 'Trace element concentrations in human enamel', Archives Oral Biol 19, 467-70.

Makowiecki, D, Zabilska-Kunek, M and Seetah, $\mathrm{K}$ et al forthcoming 2018, 'Farming, hunting and fishing in medieval Prussia, The zooarchaeological data', in Pluskowski.

Maltby, M forthcoming 2018, Animals and Archaeology in Northern Medieval Russia: Zooarchaeological Studies in Novgorod and its Region, Oxford: Oxbow.

Maltby, M, Pluskowski, A G and Rannamäe, E et al forthcoming 2018, 'Farming, hunting and fishing in medieval Livonia: The zooarchaeological data' in Pluskowski.

Motro, $\mathrm{H}$, Ellenblum, R and Rabinovitch, $\mathrm{R}$ forthcoming, Archaeozoological Evidence of a Massacre: Equid Skeletons from the Frankish Castle of Vadum lacob.

Müldner, G, Scull, C and Makowiecki D forthcoming 2018, 'Carbon and Nitrogen stable isotope evidence for animal husbandry and environmental change in the medieval Kulmerland', in Pluskowski.

Pluskowski, A G, Maltby, M and Seetah, K 2010, 'Potential osteoarchaeological evidence for riding and the military use of horses at the castle in Malbork, Poland', Internat J Osteoarchaeol 20:3, 335-43.

Pluskowski, A G (ed) forthcoming 2018, Environment, Colonisation, and the Crusader States in Medieval Livonia and Prussia: Terra Sacra 1, Turnhout: Brepols.

Pyhrr, S W LaRocca D J and Breiding D H 2005, The Armored Horse in Europe: 1480-1620, New Haven: Yale University Press.

Rackham, D J 2004, 'Physical remains of medieval horses', in C Clark (ed), The Medieval Horse and its Equipment, c. 1150-c. 1450, Woodbridge: Boydell, 19-22.

Rannamäe, E 2010, A Zooarchaeological Study of Animal Consumption in Medieval Viljandi (unpublished MA thesis, University of Tartu).

Reiche, I, Favre-Quattropani, L and Calligaro, T et al 1999, 'Trace element composition of archaeological bones and post-mortem alteration in the burial environment', Nuclear Instruments and Methods in Physics Research B 150, 656-62.

Reynard, L and Hedges, R 2008, 'Stable hydrogen isotopes of bone collagen in palaeodietary and palaeoenvironmental reconstruction', J Archaeol Sci 35, 1934-42.

Rozentāle, V et al (eds) 2007, Cēsìm 800. Quo vadis, Cēsis? Vēsture un mūsdienu nosacījumi pilsētas attīstībai, Cēsis: Cēsu pašvaldības aǵentūra, Vidzemes Vēstures un tūrisma centrs.

Russow, B 1853, Chronica der Prouintz Lyfflant : Scriptores Rerum Livonicarum, Riga and Leipzig: Eduard Frantzen's Verlags-Comtoir.

Selart, A 2015, Livonia, Rus' and the Baltic Crusades in the Thirteenth Century, Leiden: Brill.

Shiroukhov, R 2012, 'Prussian graves in the Sambian peninsula with imports, weapons and horse harnesses, from the tenth to the thirteenth century: the question of the warrior elite', Archaeol Baltica 18, 224-55.

Silver, I 1969, 'The ageing of domestic animals', in D Brothwell and E Higgs (eds), Science in Archaeology, London: Thames and Hudson, 283-302.

Spiegel, H, Sager, M and Oberforster et al 2009, 'Nutritionally relevant elements in staple foods: influence of arable site versus choice of variety', Environ Geochem Health. $<$ DOI 10.1007/s10653-009-9254-5> [Accessed 1 October 2018].

Tomsons, A 2017, 'Liecības par zirgu bruṇām Cēsu pils archeoloǵiskajā materiālā', Cēsu Pils Raksti 1, 166-79. 
Trueman, C N, Palmer, M R and Field, J et al 2008, 'Comparing rates of recrystallisation and the potential for preservation of biomolecules from the distribution of trace elements in fossil bones', Comptes Rendus Palevol 7, 145-58.

Turossa, N, Behrensmeyer, A K and Eanes, E D 1989, 'Strontium increases and crystallinity changes in taphonomic and archaeological bone', J Archaeol Sci 16, 661-72.

Vitt, V O 1952, 'Lošadi Pazyrykskikh Kurganov, [Horses of the Pazyryk Kurgans]', Sovetskaja Archeol 16, 163-205.

Walmsley, J P, Pettersson, $\mathrm{H}$ and Winberg, F et al 2002, 'Impingement of the dorsal spinous processes in 215 horses: case selection, surgical technique and results', Equine Veterinary J 34:1, 23-8.

Wilson, B and Edwards, P 1993, 'Butchery of horse and dog at Witney Palace, Oxfordshire, and the knackering and feeding of meat to hounds during the post-medieval period', Post-Medieval Archaeol 27, 43-56.

Wolski, K 2008, Polskie pola bitew w świetle archeologii, Racibórz: WAW.

Yoshinaga, J, Suzuki, T and Morita, M et al 1995, 'Trace elements in ribs of elderly people and elemental variation in the presence of chronic disease', Sci Total Environment $162,239-52$.

\section{Abbreviations:}

LUB Liv-, Est- und Kurländisches Urkundenbuch nebst regesten (Book of Certificates and Register for Livonia, Estonia and Courland) (von Bunge 1853-1857).

LGU Livländische Güterurkunden (aus den Jahren 1207 bis 1545) (von Bruiningk 1908).

SUERC Scottish Universities Environmental Research Centre

\section{TABLE TITLES}

TABLE 1

Horse element representation from trench $\mathrm{M}$ in Cēsis Castle. Capitalise Associated Bone Group in key to be consistent with text.

TABLE 2

Charred horse bones from trench $\mathrm{M}$ in Cēsis Castle.

TABLE 3

Measurements of horse bones from trench M in Cēsis Castle.

\section{FIGURE CAPTIONS}

FIG 1

Simplified plan of Cēsis Castle showing the location of trench $\mathrm{M}$ in the south-western corner of the southern outer bailey.

FIG 2

South-facing section of trench $M(A)$ and north-facing section of trench $M(B)$, with the layers associated with the horse remains highlighted in white and the horse tack indicated by $<061>$ in the south-facing section.

FIG 3

The timber at the base of trench $\mathrm{M}$, view facing north. 
FIG 4

Plan of the south-facing profile of trench $M$ showing $(A)$ the layer above associated with the stove (1.45-1.72 $\mathrm{m}$ below the surface), the phase of destruction (B), 1.75-1.85 $\mathrm{m}$ below the surface, and (C) the location of AGB1. (D) is an oblique photographic view of the southfacing section with destruction layer highlighted.

FIG 5

Associated Bone Group 1 (ABG1): (a) south-facing; (b) north-facing; (c) and (d) with the later stove positioned over the place where the horse's head lay.

FIG 6

Parts of the femur, tibia and pelvis in situ within the south-facing profile.

FIG 7

Detail of charred mid-shaft of a horse tibia fragment from trench $M$.

FIG 8

Examples of pathological vertebrae from ABG1: (a) thoracic vertebrae; (b) spinous processes from thoracic vertebrae.

FIG 9

Oxygen-hydrogen isotope plot for the Cēsis horse collagen samples. The correlation in the collagen mirrors the local meteoric water line indicating the $\mathrm{O}-\mathrm{H}$ balance in the collagen is dominated by local drinking water. The Global Mean Ocean Water trend (GMOW) is produced by natural evaporation of surface waters through the hydrological process. Local meteoric water lines are produced as small deviations from the GMOW as a result of localised conditions in evaporation and/or mixing of different water sources, but are unique to localised areas.

FIG 10

Barium-Magnesium plot for the Cēsis horse samples (Grey) in comparison to other horse samples analysed during the 'Ecology of Crusading' project.

FIG 11

Plan view of the horse tack in trench M. Note that (009) had not been fully excavated at this stage and abuts (038). This context was not clearly defined in the south-facing section and is indicated by $<061>$ on fig. $2 a$ Scale and compass direction? Several spelling errors in text on this image.

FIG 12

The horse tack in situ: (a) facing south; (b) facing west and (c) facing north-west.

FIG 13

Detail of a boss decorated with a leonine head in situ.

FIG 14 
Positive X-rays of (a) a lion bridle boss and (b) the studded disc boss from trench $\mathrm{M}$ showing bit attachments.

FIG 15

The two leonine head bosses from trench $\mathrm{M}$ before conservation: (a) front; (b) reverse, and (c) one after conservation.

FIG 16

The studded disc boss from trench $M$ before conservation (a) front; (b) reverse and (c) after conservation.

FIG 17

The plain disc boss from trench $\mathrm{M}$ before conservation.

FIG 18

Detail from 'The Ancestors of Emperor Maximilian', in 'The Procession of Emperor Maximilian I' by Albrecht Altdorfer and his workshop, showing the decorative horse tack comparable to the artefacts found in trench M. Albertina, Vienna. Reproduced with permission.

FIG 19

The unidentified iron objects in situ within the south-facing section uncovered in 2012. Suggest this figure is deleted

FIG 19

Fragment from Pisanello's tournament fresco in the Palazzo Ducale in Mantua, showing horses with brigandine barding, potentially resembling the metal objects discovered in Trench M. Describe what is shown and why it is significant? Complesso Museale di Palazzo Ducale, Mantua, Italy. Copyright etc?

FIG 20

Fragments of horse armour recovered from excavations in other areas of Cēsis Castle. Four photos, any further info on each individual one and why they are included?

FIG 21

Summary plot of AMS radiocarbon and U-Series dates for the Cēsis horse samples. Delete full stops in 'A.D.' Put AD in front of date, and be consistent. Replace 'Univ.' with 'University'

\footnotetext{
${ }^{1}$ Department of Archaeology, University of Reading, Whiteknights, Reading RG6 6AB, UK, a.g.pluskowski@reading.ac.uk

2 Department of Anthropology, Stanford University, Main Quad, Building 50, 450 Serra Mall Stanford University, Stanford, CA 94305-2034, USA, kseetah@stanford.edu

${ }^{3}$ Department of Archaeology, Anthropology and Forensic Science, University of Bournemouth, Fern Barrow, Poole, Dorset, BH12 5BB, UK, mmaltby@bournemouth.ac.uk

${ }^{4}$ Department of Archaeology, University of Reading, Whiteknights, Reading RG6 6AB, UK, r.y.banerjea@reading.ac.uk

${ }^{5}$ Department of Geography and Environmental Science, University of Reading, Whiteknights, Reading, RG6 6AB, UK, s.black@reading.ac.uk

${ }^{6}$ Cēsis Castle Museum, Pils laukums 9, Cēsis, Cēsu pilsēta, LV-4101, Latvia, Latvia, gundars.kalnins@cesis.Iv
} 


\footnotetext{
${ }^{7}$ Selart 2015.

${ }^{8}$ Kreem 2002; see also chapters on Livonia in Pluskowski forthcoming 2018. A or b? (only one 2018 forthcoming is listed for this)

${ }^{9}$ Benninghoven 1963.

${ }^{10}$ Ekdahl 1991; 1998.

11 Maltby et al forthcoming 2018 for Livonia and Makowiecki 2018 for Prussia. See also Bliujienė 2009 for a long-term Baltic overview of horses.

${ }^{12}$ Apala 2007; 2010a-c.

${ }^{13}$ The geophysics within the castle grounds were conducted by David Thornley (University of Reading). From where? NB - the department name has changed since then so I did not include it.

${ }^{14}$ Caune 2007.

${ }^{15}$ Numbers in (-) refer to archaeological contexts and numbers in <-> refer to individual finds.

${ }^{16}$ Banerjea and Badura forthcoming 2018.

17 The MNI is calculated from the MNE (minimum number of elements) by summing the zones of each element to find the most abundant, then taking the number for the most abundant element to represent the MNI for the species overall (see Hambleton 1999).
}

18 Levine 1982.

19 After Silver 1969.

${ }^{20}$ Vitt 1952.

${ }^{21}$ Makowiecki et al forthcoming 2018.

${ }^{22}$ Maltby et al forthcoming 2018.

${ }^{23}$ Makowiecki et al forthcoming 2018; see also Ekdahl 1998.

${ }^{24}$ Maltby et al forthcoming 2018.

${ }^{25}$ Maltby 2018. forthcoming? Yes.

${ }^{26}$ Baker and Brothwell 1980, 118-9; Daugnora and Thomas 2005; Levine et al 2005.

${ }^{27}$ Eg Daugnora and Thomas 2005; Pluskowski et al 2010; Janeczek et al 2014.

28 Rannamäe 2010, app 4, 109.

${ }^{29}$ Pluskowski et al 2010.

${ }^{30}$ Breiding 2005; Pyhrr et al 2005, 32.

${ }^{31}$ Walmsley et al 2002.

32 This was reported in the newspaper Pēdējā Brīdī, 26 September, 1927, in an article with the title "Zelta meklēšana" Cēsu pilsdrupās turpinās (The "Search for gold" continues at Cesis Castle). Not in bib? This is a newspaper article with no author listed. I've added as much info as I can here.

${ }^{33}$ Koon and Tuross 2013 ; Leyden et al 2006; Kirsanow et al 2008.

${ }^{35}$ Hobson et al 1999.

${ }^{36}$ Britton et al 2008.

${ }^{37}$ Reynard and Hedges 2008.

${ }^{38} \mathrm{UHQ}=$ Ultra-High Quality water, $>18 \mathrm{MOhm}$, and $\mathrm{HCl}=$ Hydrochloric acid.

${ }^{39}$ Eg Reiche et al 1999.

40 Turossa et al 1989.

41 Trueman et al 2008; Hinz and Kohn 2010.

42 Burton and Price 1990; Kohn et al 2013.

${ }^{43}$ Eg Spiegel et al 2009; González-Weller et al 2013.

${ }^{44}$ Kohn et al 2013.

$45 \mathrm{lbid}$.

${ }^{46}$ Losee et al 1974.

${ }^{47}$ Kohn et al 2013.

48 Yoshinaga et al 1995.

${ }^{49} \mathrm{REE}=$ Rare Earth Elements as defined by the IUPAC (International Union of Pure and Applied Chemistry) which are the lanthanides with scandium and yttrium.

${ }^{50}$ Kirsanow et al 2008; Reynard and Hedges 2008.

${ }^{51}$ See Müldner et al (forthcoming 2018) for a similar interpretation of a horse bone sample from the Teutonic Order's castle at Mała Nieszawka (Nessau) with a depleted $\delta^{13} \mathrm{C}$ value relative to other Prussian horses.

52 Kleimola 2005, 51. 
53 Tomsons 2017.

${ }^{54}$ Black forthcoming 2018.

55 Maltby et al forthcoming 2018.

${ }^{56}$ This depends on the size of the castle; at the extreme end of the spectrum, the central convent of Marienburg in Prussia housed up to an estimated 1000 horses in the mid-15th century in various parts of the complex (Jóźwiak and Trupinda 2012, 440, note 19).

57 LUB, 11/160, 126-9.

58 Hartmann 2008, 190.

${ }^{59}$ Dunsdorfs and Spekke 1964, 60.

${ }^{60}$ LGU, 2, 259-260.

${ }^{61}$ Russow 1853.

62 LUB, 12/133, 226.

${ }^{63}$ Bennett 1995. Not in bib. Added.

${ }^{64}$ Maltby et al forthcoming 2018; Makowiecki et al forthcoming 2018.

65 Ekdahl 1991; 1998.

${ }^{66}$ Kupisz 2012, 73, 75.

${ }^{67}$ Rackham 2004.

68 Eg London, Cowie et al 1998; Windsor, Bourdillon 1993; Witney, Wilson and Edwards 1993.

69 Motro et al forthcoming.

70 Wolski 2008, 75, 79-81.

${ }^{71}$ Shiroukhov 2012.

72 Pluskowski et al 2010.

${ }^{73}$ LaMotta and Schiffer 1999. 